https://doi.org/10.37905/sibermas.v10i3.11690

\title{
Pemberdayaan Aparat Desa Dalam Optimalisasi Program Kerja Pada RKP dan RPJM Desa Sebagai Upaya Percepatan Pencapaian SDGs Untuk Mendukung Program Desa Membangun
}

\author{
Jusna Ahmad', Febriyanti² \\ ${ }^{1,2}$ Fakultas Matematika Dan IPA, Universitas Negeri Gorontalo, Jl. Jend. Sudirman \\ No.6, Dulalowo Timur, Kota Tengah, Kota Gorontalo, Gorontalo 96128, Indonesia \\ email: jusnakahmad@gmail.com, febriyanti@ung.ac.id
}

\begin{abstract}
Abstrak
Desa Lobuto Kecamatan Biluhu Kabupaten Gorontalo memiliki banyak potensi yang perlu dikembangakan dan dilestarikan. Dalam rangka mempercepat pembangunan Desa Lobuto yang sesuai dengan undang-undang No. 25 tahun 2004 tentang sistem perencanaan pembangunan nasional, daerah dan desa, maka diperlukan langkah strategis sebagai upaya untuk pengembagan desa Lobuto yang berkelanjutan, yaitu melalui program desa membangun dalam mencapai SDGs. Oleh karena itu melalui program pengabdian masyarakat KKN Tematik Desa Membangun, diharapkan dapat membantu menganalisis program-program kerja yang tepat sasaran dan benar-benar dibutuhkan oleh masyarakat Desa Lobuto untuk dilaksanakan dengan pengembangan inovasi dan teknologi terbaru sehingga dapat berguna secara langsung bagi masyarakat untuk peningkatkan ekonomi, kesejahteraan masyarakat, peningkatan sosial budaya dan kesehataan untuk mendukung program Desa Membangun dalam pencapaian SDGs. Berdasarkan hasil analisis dan assessment di lapangan dirumuskan program kegiatan yang sangat urgent dan dianggap sesuai dengan kebutuhan masyarakat Desa Lobuto, yaitu : (1). Pengembangan wisata pantai , (2). Pengelolaan dan pemasaran hasil tankap perikanan, (3). Perencanaan pembuatan perpustakaan Desa, (4). Pembuatan Bank Sampah dan didukung dengan beberapa program tambahan lainnya seperti (1). Pelaknsanaan Tumbilotohe dan (2). Kegiatan Hiburan untuk masyarakat. Program kegiatan yang tersebut akan dmasukan dalam rencana kerja pembangunan (RKP) Desa Lobuto Kecamatan Biluhu Kabupaten Gorontalo.
\end{abstract}

Kata Kunci : Pembangunan Desa, Program Kerja, RKP Desa

\begin{abstract}
Lobuto Village, Biluhu District, Gorontalo Regency has a lot of potential that needs to be developed and preserved. In order to accelerate the development of Lobuto Village in accordance with Law No. 25 of 2004 concerning the national, regional and village development planning system, strategic steps are needed as an effort for the sustainable development of Lobuto village, namely through the village development program in achieving the SDGs. Therefore, through the Community Service Program the Thematic Village Community Service Program, it is hoped that it can help analyze work programs that are right on target and really needed by the Lobuto Village community to be implemented with the development of the latest innovations and technology so that they can be used directly for the community to improve the economy, community welfare, socio-cultural improvement and health to support the
\end{abstract}


Village Build program in achieving the SDGs. Based on the results of the analysis and assessment in the field, a program of activities that are very urgent and considered appropriate to the needs of the Lobuto Village community are formulated, namely: (1). Coastal tourism development, (2). Management and marketing of fishery products, (3). Planning for making village libraries, (4). Construction of a Waste Bank and supported by several other additional programs such as (1). Tumbilotohe implementation and (2). Entertainment activities for the community. The program of activities will be included in the development work plan (RKP) of Lobuto Village, Biluhu District, Gorontalo Regency.

Keywords: Village Development, Work Program, RKP Village

(C) 2021 Jusna Ahmad, Febriyanti Under the license CC BY-SA 4.0 Correspondence author: Febriyanti, febriyanti@ung.ac.id, Gorontalo, Indonesia

\section{PENDAHULUAN}

Dalam rangka mempercepat pembangunan Desa Lobuto Kecamatan Biluhu Kabupaten Gorontalo yang sesuai dengan undangundang No. 25 tahun 2004 tentang sistem perencanaan pembangunan nasional, daerah dan desa. Maka diperlukan langkah strategis sebagai upaya untuk pengembagan desa Lobuto yang berkelanjutan, yaitu melalui program desa membangun dalam mencapai SDGs.

Sustainable Development Goals (SDGs) Desa adalah upaya terpadu mewujudkan Desa tanpa kemiskinan dan kelaparan, Desa ekonomi tumbuh merata, Desa peduli kesehatan, Desa peduli lingkungan, Desa peduli pendidikan, Desa ramah perempuan, Desa berjejaring, dan Desa tanggap budaya untuk percepatan pencapaian tujuan pembangunan berkelanjutan. SDGs Desa merupakan role pembangunan berkelanjutan yang akan masuk dalam program prioritas penggunaan Dana Desa Tahun 2021. Dengan SDGs Desa maka diharapkan arah tujuan pembangunan di Desa Lobuto Kecamatan Biluhu Kabupaten Gorontalo akan lebih terarah, terukur dan mandiri 
dengan melibatkan semua pihak yang ada di desa serta mengoptimalkan potensi desa yang ada.

Melalui program pengabdian masyarakat KKN Tematik Desa Membangun yang telah dilaksanakan di Desa Lobuto Kecamatan Biluhu Kabupaten Gorontalo, dengan berdasarkan padan sasaran RENSTRA Kemendes PDTT Tahun 2020 - 2024 dengan Kerangka Logis KKNT Desa Membangun, bertujuan untuk :

1. Mendorong terwujudnya Desa Berkembang dan Mandiri, serta kolaborasi perdesaan dengan perkotaan melalui pengembangan Kawasan Perdesaan secara berkelanjutan.

2. Mendorong tumbuhdan berkembangnya investasidi desa dan perdesaan, daerah tertinggal, dan Kawasan transmigrasi.

3. Meningkatnya pengetahuan masyarakat serta mampu melakukan inovasi berdasarkan hasil pengabdian dosen untuk meningkatkan taraf hidup masyarakat sesuai pencapaian SDGs.

Berdasarkan tujuan tersebut, untuk implementasi dan pencapaian SDGs di Desa Lobuto Keca. Biluhu Kab. Gorontalo, maka diperlukan prioritas dan fokus pembangunan desa diantaranya melalui penyusunan Rencana Kerja Pembangunan (RKP) Desa Lobuto untuk lima tahun kedepan yaitu periode 2021-2025 dengan menerapkan pembangunan berkelanjutan tingkat desa sesui dengan pencapaian SDGs. Dokumen perencanaan pembangunan desa/RKP desa diharapkan dapat mengacu pada dokumen perencanaan pembangunan daerah nasional. Salah satu instrumen kebijakan yang diluncurkan oleh pemerintah dalam rangka mewujudkan desa yang maju, mandiri, dan sejahtera yang tertuang dalam undang-undang No. 6 tahun 2014. Untuk memenuhi hal tersebut, terdapat ada dua hal 
penting yang diberikan kepada desa dalam rangka mempercepat terjadinya perubahan di desa menuju kondisi yang lebih baik, yaitu:

1. Desa diberikan kewenangan untuk mengatur dan mengurus kepentingan masyarakatnya, melalui kewenangan desa berdasarkan hak asal usul dan kewenangan lokal berskala desa.

2. Desa saat ini mendapatkan dukungan pendanaan yang memadai dalam bentuk dana transfer dari pemerintah dan pemerintah kabupaten. Kewenangan desa yang besar dan didukung oleh kapasitas keuangan yang memadai, diharapkan akan mampu mempercepat pemberdayaan desa menuju desa yang kuat, maju, mandiri dan sejahtera.

Saat ini di Desa Lobuto masih sangat kurang program kerja desa yang dilaksanakan untuk peningkatan ekonomi dan kesejahteraan msayarakat, dikarenakan kurangnya pengetahuan dan edukasi terhadap masyarakat dan pemerintah desa setempat. Oleh karena itu melalui program pengabdian masyarakat KKNT Desa membangun, diharapkan dapat membantu menganalisis program-program kerja yang tepat sasaran dan benar-benar dibutuhkan oleh masyarakat Desa Lobuto untuk dilaksnaakan dengan pengembangan inovasi dan teknologi terbaru sehingga dapat berguna secara langsung bagi masyarakat untuk peningkatkan ekonomi, kesejahteraan masyarakat, peningkatan sosial, budaya dan kesehataan untuk mendukung program Desa Membangun dalam pencapaian SDGs. Sehingga pada masa yag akan datang, program-program kerja yang diusulkan dan akan dimasukan di dalam RKP Desa Lobuto harus sesuai dengan kebutuhan masyarakat Desa Lobuto dan sudah berdasarkan hasil analisis dan assessment dilapangan. Berdasarkan analisis situasi tersebut, maka 
diharapakan dengan pelaksanaan program pengabdian pada masyarakat melalui KKN Tematik Desa Membangun dapat membantu pemerintah desa dalam mengoptimalkan program kerja desa yang akan dimasukan dalam RKP Desa untuk memprcepat perencanaan pembangunan Desa sesuai pencapaian SDGs.

\section{METODE PELAKSANAAN}

Metode pelaksnaan yang digunakan dalam pelaksnaan kegiatan pengandian KKN Tematik Desa Membangun, yaitu :

\section{Persiapan}

a. Observasi

Observasi diawali dengan melakukan observasi langsung dan analisis kebutuhan masyarakat Desa Lobuto oleh Mahasiswa peserta KKN Tematik Desa Membangun mengenai kehidupan keseharian masyarakat Desa Lobuto, potensi yang dimiliki Desa Lobuto yang dapat menunjang pembangunan desa, yang selanjutnya hasil analisis tersebut akan diuraikan dalam bentuk program kerja yang nantinya akan diusulkan ke pemerintah Desa Lobuto sebagai program kerja pembangunan desa.

b. Perencanaan

Dalam rangkan penyusunan program kerja pembangunan desa maka pada tahap perencanaan ini terdapat beberapa kegiatan yang dilakukan oleh Mahasiswa peserta KKN Tematik Desa membangun yaitu :

- Membantu perumusan materi untuk penyusunan atau revisi RPJM Desa

- Membantu perumusan materi untuk penyusunan RKP Desa tahun berikutnya. 
- Memfasilitasi pertemuan desa untuk membahas masukan dari hasil asesmen, untuk dokumen RPJM Desa dan dokumen RKP Desa.

- Memfasilitasi pertemuan desa untuk menyepakati masukan dari hasil asesmen, untuk dokumen RPJM Desa dan dokumen RKP Desa.

- Menyusun jadwal kegiatan pelaksaan program.

- Membentuk panitia pelaksana masing-masing program kegiatan yang telah diusulkan.

\section{Pelaksanaan}

Pada tahap ini, semua program kerja yang telah diusulkan ke pemerintah Desa Lobuto dan telah disetujui pada pertemuan desa dilaksanakan sesuai dengan jadwal dan waktu yang sudah disepakati yang diawali dengan kegiatan sosialisasi program yang kepada masyarakat Desa Lobuto. Selanjutnya untuk mendukung program agar terlaksna dengan baik dalam pelaksanaanya dihadirkan para narasumber yang kompoten sesuia dengan jenis program yang dilaksanakan.

3. Evaluasi

Tahap terakhir dari kegiatan pengabdian pada masyarakat melalui KKN Tematik Desa membangun adalah evalusi seluruh kegiatan yang telah dilaksanakan.

\section{HASIL DAN PEMBAHASAN}

\section{Hasil}

Desa Lobuto memiliki banyak potensi yang perlu dikembangakan dan dilestarikan. Dari hasil observasi dilapangan yang telah dilakukan pada tanggal 7 April 2021, diperoleh fakta bahwa potensi yang ada di 
Desa Lobuto tidak terkelolah dengan baik karena belum dilakukannya analisis kebutuhan program yang urgent yang dibutuhkan oleh masyarakat guna peningkatan ekonomi dan pembangunan Desa Lobuto. Berdasarkan Analisa situaisi tersebut, maka berdasarkan hasil observasi di lapangan diperoleh beberapa program kegiatan yang menjadi kebutuhan masyarakat Desa Lobuto untuk percepatan pembangunan desa dengan persentasi berbeda untuk setiap program (Gambar 1).

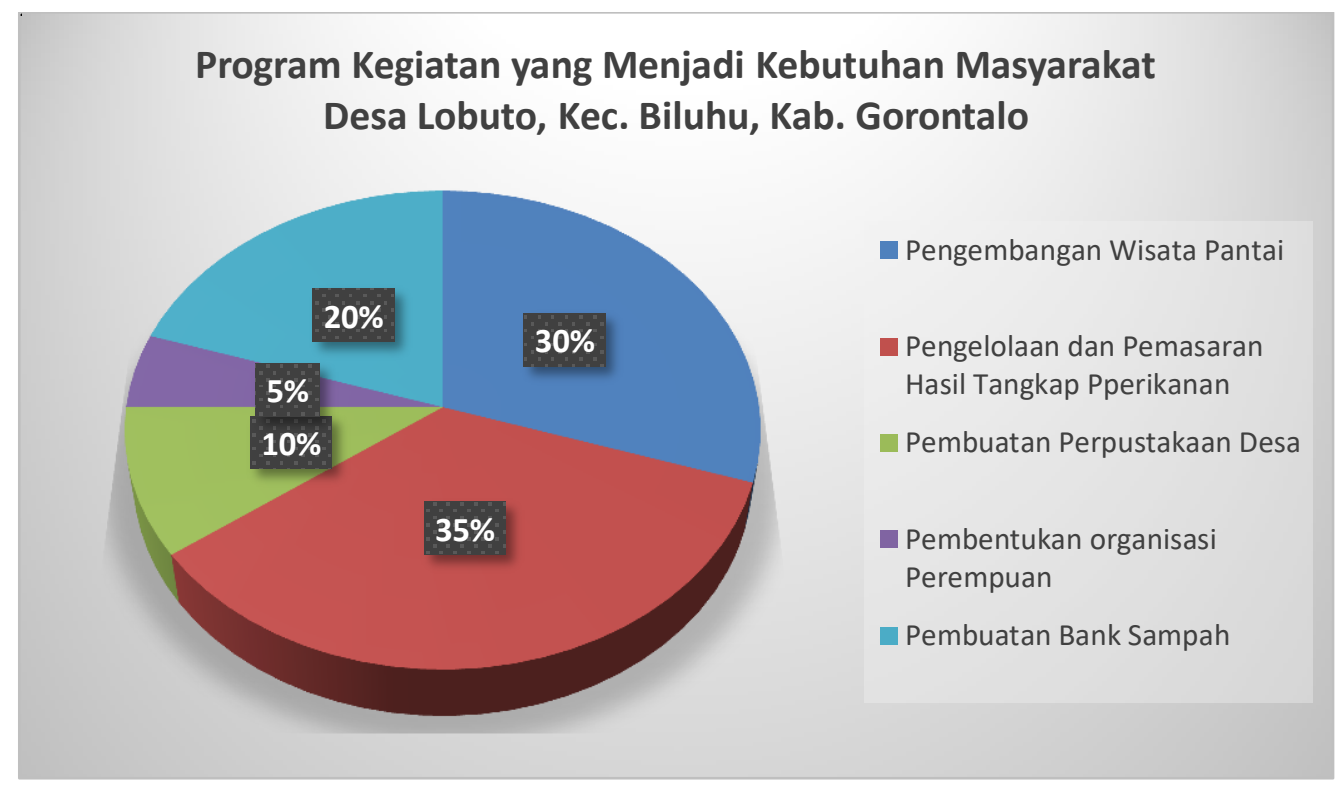

Gambar 1. Persentase Program Kegiatan Yang Menjadi Kebutuhan Masyarakat Desa Lobuto

\section{Rencana Penyelesaian}

Adapun rencana penyelesaian program yaitu :

1. Penyesuaian/adaptasi dengan lingkungan masyarakat Desa Lobuto. Hal ini dilakukan dengan mulai membuka diri dengan masyarakat Desa Lobuto serta membangun komunikasi yang baik. Khususnya bersama kelompok rema muda yang merupakan salah satu aspek 
yanga akan sangat mendukung dan membantu dalam proses pemyelesaia program kerja yang sudah rencnakan.

2. Bersama pemerintah desa mendiskusikan rencana program kerja dan bersama-sama melakukan analisis kebutuhan masyarakat Desa Lobuto

3. Mendampingi pemerintah desa pada proses Evaluasi Program Kerja desa. Agenda kegiatan yang telah disusun dan direncanakan untuk jangka waktu tertentu dan telah disepakati secara mufakat, dianalisis dan dievaluasi kembali terkait kendala misalnya persoalan pendanaan dan juga persiapan. Untuk mengantisipasi hal tersebut, kami membantu pemerintah desa setempat dalam melakukan evaluasi program kerja. Dalam proses pelaksnaannya kami membentuk panitia pelaksana sesuai dengan kegiatan evaluasi dan menunjuk masing-masing penanggung jawab yang melibatkan kelompok Rema-Muda Desa Lobuto dalam setiap kegiatan, baik program inti ataupun program tambahan.

\section{PEMBAHASAN}

\section{Realisasi Pelaksanaan Program Kerja}

Dalam pelaksanaan program pengabdian masyarakat melalui KKN Tematik Desa Membangun di Desa Lobuto, Kecamatan Biluhu, Kabupaten Gorontalo. Ada beberapa program yang telah direncanakan yang telah disetujui oleh pemerintah desa pada saat musyawarah dan rapat penentuan program desa. Program tersebut sudah berdasarkan hasil observasi dan analisis kebutuhan masyarakat Desa Lobuto, baik program yang berdasarkan di 18 Topologi SDGs dan juga ada beberapa program tambahan. Program yang sesuai dengan topologi 
SDGs yang telah mendapat persetujuan dari pemerintah Desa Lobuto dan telah dilaksnakan yaitu :

a. Pengembangan Wisata Pantai

- Persiapan

1. Rapat koordinasi bersama kelompok Rema Muda Desa Lobuto dan Stakeholder (Kepala Desa dan aparat Desa, Tokoh Adat)

2. Pembentukan panitian pelaksasana kegiatan sosialisasi pengembangan wisata pantai

3. Sosialisasi mengenai pembentukan Pokdarwis (Kelompok Sadar Wisata)

4. Persiapan administrasi untuk Musyawarah Besar ke-I pembentukan Pokdarwis Desa Lobuto

5. Pelaksanaan Musyawarah Besar ke-I Pokdarwis Desa Lobuto.

- Pelaksanaan

Masyarakat sebagi salah satu pemangku kepentingan turut berpartisipasi dan berperan aktif pada pelaksnaan program ini. Pengembangan wisata pantai diawli dengan kegiatan sosialisai kepada masyarakat Desa Lobuto mengenai potensi wisata pantai yang ada di Desa Lobuto dengan menghadirkan pembicara dari salah satu instansi bidang kepariwisataan Provinsi Gorontalo, yang banyak memberikan masukan serta pengetahuan kepada pamsyarakat akan potensi pantai sebagai agen wisata yang jika dikeloah dengan baik maka dpat meningkatkan pertumbuhan ekonomi desa (Gambar 2). 


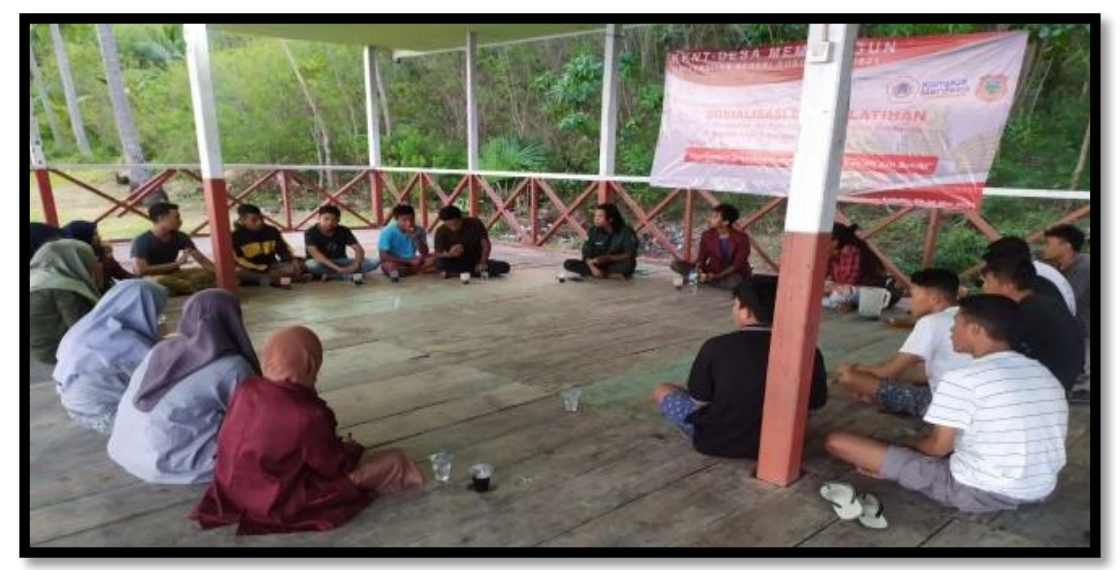

Gambar 2. Keaiatan Sosialisasi Penaembanaan Wisata Pantai Desa Lobuto

Melalui kegiatan sosialisai pengembangan wisata pantai, maka kemudian dibentuk kelembagaan kelompok sadar wisata (Pokdarwis) di Desa Lobuto Kecamatan Biluhu Kabupaten Gorontalo.

b. Membuat Perpustakaan Desa

Dari hasil observasi banyak masyarakat Desa Lobuto yang kurang melanjutkan pendidikan karena jarak yang cukup jauh dengan ibu kota kecamatan lokasi Sekolah, sehingga membuat masyarakat enggan melanjutkan pendidikan. Oleh karena itu hal ini menjadi salah satu permasalahan yang perlu ditindaki oleh pemerintah Desa setempat melalui sebuah inovasi pendidikan yaitu pembuatan perputaakaan Desa. Namun melihat banyaknya kendala di lapangan program ini tidak bisa terlaksana pada masa kegiatan KKNT, karena untuk realisasinya pembuatan perpustakaan desa memiliki langkah prosedurnya senidiri karena sudah menyangkut penggunaan anggrana desa.

c. Membuat Bank Sampah Desa

Sebagai tindak lanjut dan realisasi program yang pembuatan bank sampah diawali dengan sosialisasi dan pendampingan 
pengelolaan sampah pada masyarakat mulai dari pemilihan, pemilahan, pengumpulan, pengangkutan, pengolahan dan pemrosesan akhir. Pengelolaan sampah melalui pembuatan bank sampah yang dimaksudkan untuk pelestarian dan kebersihan lingkungan khususnya pada masa pandemic COVID-19 yang masih mewabah, maka program bank sampah sangat perlu untuk disosialisasikan serta dilatihkan pada asyarakat Desa Lobuto, agar masyarakat tau dan paham cara mengelolah sampah yang benar.

d. Pelatihan Pengelolaan dan Pemasaran Hasil Tangkap Ikan

- Persiapan

1. Rapat koordinasi bersama kelompok Rema Muda Desa Lobuto dan Stakeholder (Kepala Desa dan aparat Desa, Tokoh Adat)

2. Pembentukan panitian pelaksasana kegiatan sosialisasi ,pelatihan dan marketing digital hasil tangkap perikanan

3. Implementasi dan praktek secara langsung bersama masyarakat dengan menghadirkan pemateri

- Pelaksnaan

Sumber daya alam yang plaing melimpah di Desa Lobuto adalah hasil tangkap perikanan. Akan tetapi masyarakat yang kurang paham dalam melakuakn pengelolaan dan pemasaran hasil tangkapan ikan sehingganya ikan yang ditangkap hanya dijual mentah ke masyarakat sekitar Padahal jika ada produk kreativitas dan inovasi yang bisa dihasilkan dari hasil tangkap perikanan yang melimpah maka akan sangat berdampak bagi perkembangan ekonomi masyarakat Desa Lobuto. untuk mensukseskan program ini pemerintah desa dengan difasilitasi Mahasiswa KKNT melaksnakan kegiatan sosialisasi dan pelatihan serta Digital Marketing hasil 
tangkap perikanan dengan focus utama peserta adalah kaum perempuan. pelaksnaan kegiatan ini tidak hanya sekadar sosialisasi dan penyampaian materi oleh Narasumber tetapi juga langsung mempraktekan Bersama dengan kelomok ibu-ibu bagaimana inovasi pengolahan ikan menjadi beberapa produk olahan rumah tangga seperti bakso ikan, nuget ikan dan kerupuk ikan serta Narasumber turut mempraktekan cara pemasaran melalui platform media sosial seperti Facebook, Intragram dan Tiktok (Gambar 3.)

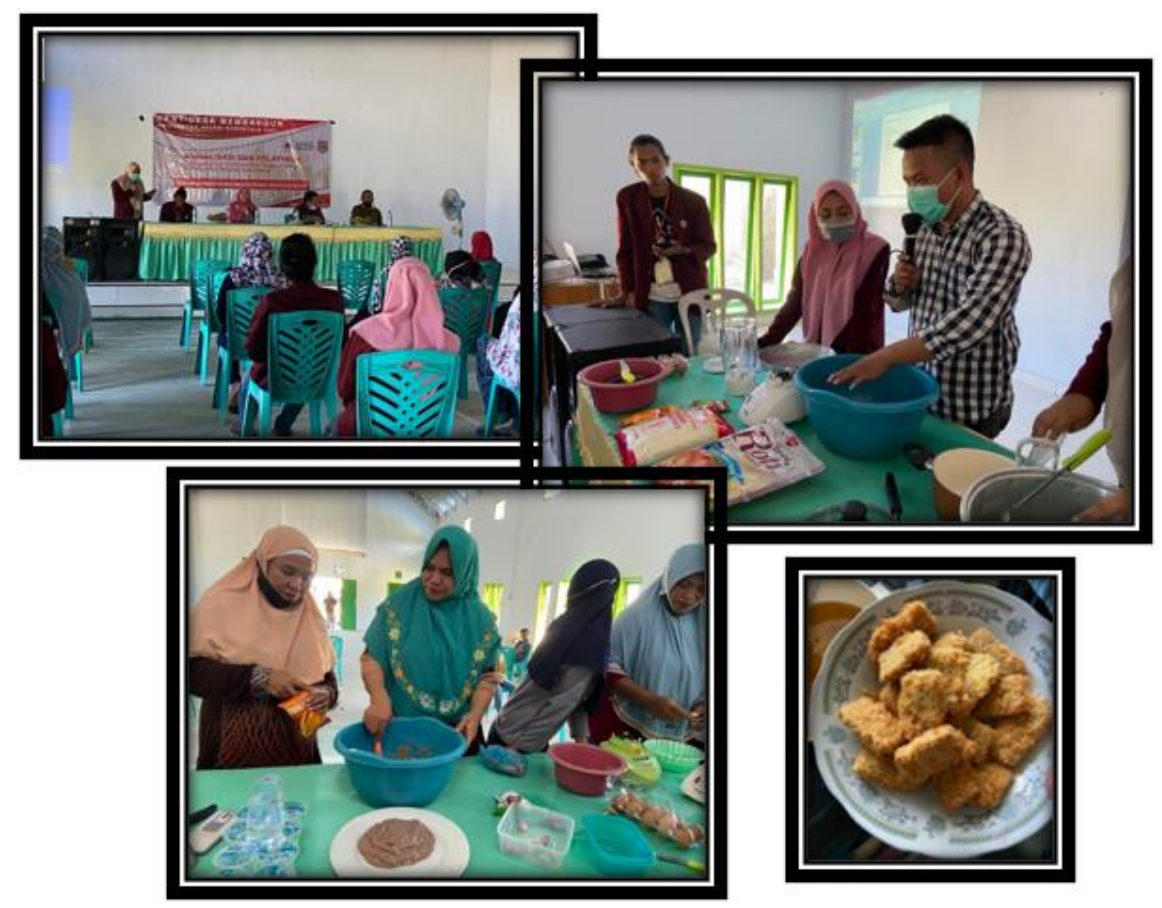

Gambar 3. Kegiatan Sosialisasi dan Pelatihan Pengolahan dan Pemasaran Hasil Tanqkap Perikanan di Desa Lobuto Kec. Biluhu Kab. Gorontalo

Selain program kerja yang sesuai dengan tipe desa SDGs, juga terdapat beberapa rogram tambahan yang telah dilaksnakan dan sudah mendapat persetujuan dari pemeritah desa dan masyarajat Desa Lobuto, yaitu: 


\section{a. Pelaksnaaan Lomba Malam Tumbilotohe \\ b. Pelaksnaan Hiburan Rakyat}

Dari kelima program kerja yang sesuai dengan program desa membangun untuk pencapaian SDGs yang telah direncanakan, hanya dua program kerja yang dapat terealisasi dan sesuai dengan rencana dan tahapan-tahapan yang sudah disusun, mulai dari awal perencanaan sampai dengan pelaksanaan program kerja. Kedua program inti tersebut yaitu, pengembangan wisata pantai dan pelatihan pengelolaan dan pemasaran (marketing digital) hasil tangkap ikan. Perencaaan program kerja ini telah disusun sebaik mungkin, meskipun terdapat banyak kendala yang tidak di duga, baik fisik maupun teknis. Sedangkan untuk program tambahan terlaksna 100\%.

\section{Hambatan/ Permasalahan dalam Pelaksaan Program}

Adapun hambatan/permasalahan yang muncul sehingga banyak program kerja yang telah direncanakan tidak terealisasi diantaranya :

- Waktu pelaksnaan KKN T yang singkat, sehingga pelaksanaan observasi dan analisis kebutuhan masyarakat yang dilakukan juga cukup singkat sehingga masih bayak kebutuhan masyarakat dan potensi lain dari Desa Lobuto yang tidak diperoleh

- Kurangnya persatuan antar kelompok Rema Muda dalam kesadaran membangun Desa, sehingga semangat dalam melaknsakan program kerja yang sudah disusun dan direncanakan sangat kurang

- Kurangnya dukungan dan tanggapan positif dari masyarakat kiranya dalam program tersebut memerlukan bantuan dana,

- Sulitnya berkomunikasi dengan masyarakat setempat karena banyak yang menggunakan Bahasa daerah dan minim Bahasa Indonesia 
- Keterlambatan sosialisi oleh Pemerintah Desa terhadap program kerja yang akan dilaksnakan yang dikarenakan Desa Lobuto masih dalam masa pergantian kepala desa yang baru.

\section{Rencana Penyusunan Rencana Kerja Program (RKP) Desa Lobuto}

Dalam pelaksanaanya program kerja yang akan dimasukan dalam RKP Desa Lobuto yang sudah dinalaisis berdasarkan kebutuhan masyarakat belum bisa disahkan, hal ini dikarenakan adanya pergantian Kepala Desa yang baru saja dilaksanakan serentak diseluruh Kab. Gorontalo, dan waktu pelaksanaan KKN Tematik yang hanya 66 hari tidak memungkinkan untuk bisa menunggu serah terima jabatan kepla desa berikutnya. Sehingga hanya draft usulan program yang telah dilaksanakan dan yang belum terlaksana saja yang telah diarsipkan di Desa Lobuto yang nantinya akan digunakan sebagai dasar untuk pengesahan RKP Desa Lobuto akan datang. Adapun alur penyusunan RKP Desa Lobuto sebelumnya yaitu :

a. Musyawarah antar pihak desa

b. Pembentukan tim penyusunan RKP desa

C. Pencermatan Pagu indikatif desa dan Penyelarasan

Program/Kegiatan Masuk Ke Desa

d. Pencermatan ulang RPJM Desa

e. Penetapan RKP Desa Melalui Musrenbang Desa

f. Tahapan Perubahan RKP Desa

g. Pengajuan Daftar usulan RKP Desa 


\section{KESIMPULAN}

Dalam waktu 66 hari mahasiswa peserta KKNT desa membangun di Desa Lobuto telah berupaya mendata, menganalis dan melakukan assessment terhadap kebutuhan masyarakat Desa Lobuto dalam mendukung pembangunan dan pengembangan Desa Lobuto Kecamatan Biluhu Kabupaten Gorontalo. Sebagian program kerja yang direncanakan telah terlaksana dengan baik, namun tidak dapat dipungkiri terdapat banyak sekali hambatan dalam prosesnya. Program-program kegiatan yang telah dilaksnakan tersebut nantinya akan dimuat dalam RPJM dan RKP Desa Lobuto, walapun dalam proses pengesahannya tidak melibatkan mahasiswa peserta KKNT, tetapi sejauh ini bantuan mahasiswa KKNT terhadap perkembangan desa disambut baik dan mendapat dukungan dari pemerintah, aparat serta sebagian besar masyarakat Desa Lobuto.

\section{UCAPAN TERIMA KASIH}

Kesuksesan dan kelancaran kegiatan pengabdian kepada masyarakat melalui KKN Tematik Desa Membangun tidak akan berhasil tanpa support dari perguruan tinggi dalam hal ini adalah Lembaga Penelitian dan Pengabdian kepada Masyarakat (LPPM) Universitas Negeri Gorontalo sebagai penyedia dana hibah pengabdian kepada masyarakat yang telah menugaskan kami selaku dosen pada kegiatan pengbdian ini. Tak lupa kami ucapkan terima kasih pada pemerintah Kabupaten Gorontalo serta masyarakat Desa Lobuto Kecamatan Biluhu Kabupaten Gorontalo atas dukungan dan fasilitas yang telah disediakan dalam mendukung program KKNT Desa Membangun periode 1 yang diselenggrakan oleh Uninversitas Negeri Gorontalo. 


\section{REFERENCES}

Djafar, R., \& Sune, U. (2019). Pengentasan Kemiskinan Berbasis Pemberdayaan Masyarakat di Kabupaten Pohuwato. Madani Jurnal Politik Dan Sosial Kemasyarakatan, 11(3), 246270.

Jume'edi. (2005). Peran Wanita dalam Meningkatkan Pendapatan Keluarga Nelayan di Kelurahan Ujungbatu Kecamatan Jepara Kabupaten Jepara. Tesis. Program Pasca Sarjana Undip Semarang

Kusnadi. (2010). Kebudayaan Masyarakat Nelayan dalam Jelajah Budaya Tahun 2010. Yogyakarta: Kementerian Kebudayaan Pariwisata

Panduan Fasilitasi Penyusunan Rencana Kerja Pemerintah Desa (RKP Desa) Tahun 2020.

Rancangan Renstra 2020-2024. Kementerian Desa, Pembangunan Daerah Tertinggal Dan Transmigrasi Republik Indonesia. https://www.kemendesa.go.id/berita/view/publikasi/359/rancanga n-renstra-2020-2024

Undang-undang Republik Indonesia Nomor 6 tahun 2014 Tentang Desa Membangun.

Zein, A. (2006). Peningkatan Ekonomi Rumah Tangga Nelayan Melalui Pemberdayaan Wanita Nelayan. Mangrove dan Pesisir Vol. VI No. 1/2006. 